\title{
Changes in area and geodetic mass balance of small glaciers, Polar Urals, Russia, 1950-2008
}

\author{
Maria SHAHGEDANOVA, ${ }^{1}$ Gennady NOSENKO, ${ }^{2}$ Irina BUSHUEVA, ${ }^{2}$ \\ Mikhail IVANOV ${ }^{2}$ \\ ${ }^{1}$ Department of Geography and Environmental Science and Walker Institute for Climate System Research, \\ University of Reading, Reading, UK \\ E-mail: m.shahgedanova@reading.ac.uk \\ ${ }^{2}$ Institute of Geography, Russian Academy of Sciences, Moscow, Russia
}

\begin{abstract}
Changes in area of 30 small glaciers $\left(\operatorname{mostly}<1 \mathbf{k m}^{2}\right)$ in the northern Polar Urals $(67.5-$ $68.25^{\circ} \mathrm{N}$ ) between 1953 and 2000 were assessed using historic aerial photography from 1953 and 1960 , ASTER and panchromatic Landsat ETM+ imagery from 2000, and data from 1981 and 2008 terrestrial surveys. Changes in volume and geodetic mass balance of IGAN and Obruchev glaciers were calculated using data from terrestrial surveys in 1963 and 2008. In total, glacier area declined by $22.3 \pm 3.9 \%$ in the 1953/60-2000 period. The areas of individual glaciers decreased by $4-46 \%$. Surfaces of Obruchev and IGAN glaciers lowered by $22.5 \pm 1.7 \mathrm{~m}$ and $14.9 \pm 2.1 \mathrm{~m}$. Over 45 years, geodetic mass balances of Obruchev and IGAN glaciers were $-20.66 \pm 2.91$ and $-13.54 \pm 2.57 \mathrm{~m}$ w.e. respectively. Glacier shrinkage in the Polar Urals is related to a summer warming of $1^{\circ} \mathrm{C}$ between $1953-81$ and 1981-2008 and its rates are consistent with other regions of northern Asia but are higher than in Scandinavia. While glacier shrinkage intensified in the 1981-2000 period relative to 1953-81, increasing winter precipitation and shading effects slowed glacier wastage in 2000-08.
\end{abstract}

\section{INTRODUCTION}

Glaciers in most parts of the world are currently receding in response to climatic warming (Solomon and others, 2007). The loss of glacier mass leads to changes in the local and regional water balance and to global sea-level rise. Modelling studies suggest that very small glaciers (e.g. $<0.5 \mathrm{~km}^{2}$ ) will respond most strongly to the projected climatic warming (Oerlemans and others, 1998). A number of observational studies have convincingly demonstrated the enhanced vulnerability of very small glaciers to observed climatic warming (e.g. Paul and others, 2004; Granshaw and Fountain, 2006; Bolch and others, 2010). However, the strong links between the behaviour of very small glaciers and local topographic and climatic factors (Evans, 2011) make their response to climatic warming less certain (Kuhn and others, 1985; Hoffman and others, 2007; DeBeer and Sharp, 2009; Abermann and others, 2011). Assessments of responses of very small glaciers to climatic warming are hampered by a lack of data: such glaciers are often excluded from analyses due to difficulties in the application of satellite remote-sensing techniques and lack of massbalance monitoring. To improve our understanding of the response of very small glaciers to the observed climatic warming and to inform future projections, it is important to investigate their behaviour in regions with various climatic and topographic conditions.

The Ural Mountains, a range dividing geographical Europe and Asia, is a region where very small glaciers are widespread. Glaciers exist north of $64^{\circ} \mathrm{N}$ in the the Polar $\left(66-68^{\circ} \mathrm{N}\right)$ and Subpolar $\left(64-66^{\circ} \mathrm{N}\right)$ Urals (Fig. 1). Research into the glaciers of the Urals dates back to the early 1930s, when selected glaciers of the Subpolar Urals were first mapped (Alsehkov, 1935; Boch, 1935). Extensive aerial surveys were conducted in the 1950s and 1960s and their results were summarized in the catalogue of glaciers of the
USSR (Troitskiy and Kemmerikh, 1966) and by Troitskiy and others (1966) and Khodakov (1978). According to these data, available as part of the World Glacier Inventory (WGI) from the US National Snow and Ice Data Center, Boulder, CO (Bedford and Haggerty, 1996; http://nsidc.org/data/ glacier_inventory/), there were 143 glaciers in the Polar and Subpolar Urals with a combined area of $28.66 \mathrm{~km}^{2}$. A regular glacier monitoring programme in the region continued between 1957 and 1981, and mass-balance observations of two reference glaciers, IGAN and Obruchev, were reported to the World Glacier Monitoring Service (http:// www.wgms.ch). Although, by the 1980s, glacier wastage had already been observed in the region (Tsvetkov and Tyuflin, 1981; Tsvetkov, 2006), regular glaciological monitoring was discontinued. This resulted in a lack of data about the behaviour of the glaciers of the Urals, at a time when intensified retreat of small glaciers was reported worldwide (Dyurgerov and Meier, 2000; Kaser and others, 2006).

Brief field surveys conducted in 2002 and 2005, in the Subpolar and Polar Urals respectively, revealed dramatic changes: not only had glaciers shrunk significantly, but some (e.g. Manaraga and Balban in the Subpolar Urals) disappeared and were replaced by newly formed lakes (Glazovskiy and others, 2005). A further study of six Polar Ural glaciers by Solomina and others (2010) reported a considerable wastage of three glaciers (IGAN, Obruchev and Berg), which lost 30-50\% of their length between 1953 and 2008, but very small changes in the positions of the termini of the other three (Shumskiy, Avsyuk and Anuchin), confirming a wide range of responses of small glaciers to climatic warming. This varying behaviour is in line with earlier reports which also emphasized varied responses of the Polar Ural glaciers to climatic fluctuations, and is enhanced by the dependency of the regional glaciers on snowdrift and their orientation in the lee of westerly winds (Dolgushin, 1961). 


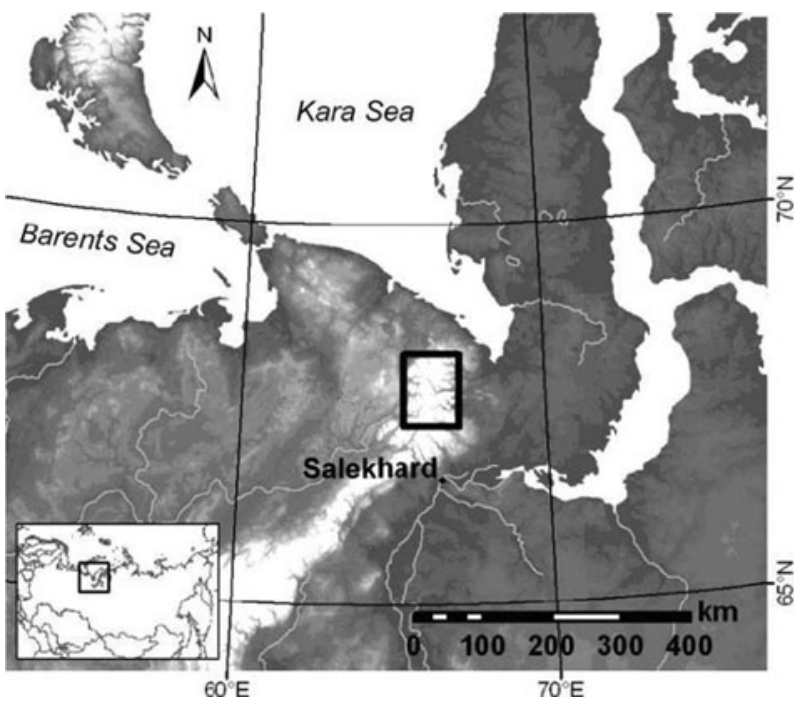

Fig. 1. Glacier study area. Black rectangles show location of the Polar Urals (inset map) and glacierized study area (main map).

According to Tsvetkov (2006), while the terminus positions of IGAN, Anuchin, MGG and Karskiy glaciers did not change between 1953 and 1981, that of MGU glacier receded by $850 \mathrm{~m}$ (i.e. $30 \mathrm{~m} \mathrm{a}^{-1}$ ) in the same time interval, while most other glaciers receded at slower rates of $2-5 \mathrm{~m} \mathrm{a}^{-1}$.

The lack of recent data on glacier change and the reported diversity of responses of individual glaciers make it important to investigate changes in map area of a larger sample of glaciers in the Polar Urals as well as changes in glacier volume and mass balance. Not only will this information improve our knowledge of the diverse behaviour of small glaciers under climatic warming, but it will contribute to our understanding of glacier change in the Arctic fringe. This paper presents the first comprehensive survey of small glaciers in the Polar Urals since termination of the regional glacier monitoring programme in 1981. The objectives of the paper are to: (1) quantify changes in the area of 30 glaciers between 1953 (the years of the previous large-scale glacier inventories (Tables 1 and 2) and the early 21st century; (2) quantify changes in surface elevation and volume and calculate geodetic mass balances for two formerly reference glaciers (Obruchev and IGAN) between 1963 and 2008; and (3) relate the observed glacier changes to changes in regional air temperature and precipitation. Glaciological mass-balance records for IGAN and Obruchev glaciers, dating back to the 1958-80 period, are among the earliest mass-balance records in Russia and it is envisaged that the estimated geodetic mass-balance data will supplement the earlier glaciological data (despite the differences in their instrumental and physical biases) and help to validate mass-balance records reconstructed from proxy data.

\section{STUDY AREA}

The present glacier region of the Polar Urals extends between $66.5-68.25^{\circ} \mathrm{N}$ and $63.8-66.4^{\circ} \mathrm{E}$ (Fig. 1), and most glaciers are located between $66.5-67.0^{\circ} \mathrm{N}$ (southern sector) and $67.5-68.25^{\circ} \mathrm{N}$ (northern sector and the study area). The elevations range mostly between 300 and 1400 ma.s.I., with a maximum of $1640 \mathrm{~m}$ a.s.I. Within the Polar Urals, the WGI (http://nsidc.org/ data/glacier_inventory/) listed 91 glaciers with a combined area of $20.8 \mathrm{~km}^{2}$ in the $1953-60$ period. In

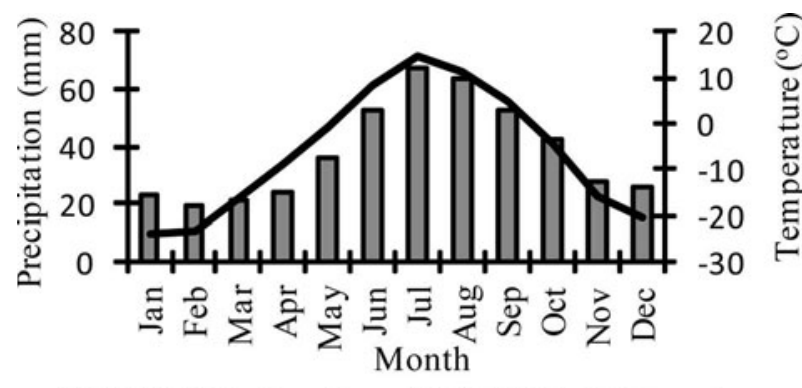

Precipitation

Air temperature

Fig. 2. Monthly precipitation and air temperature at Salekhard meteorological station from 1952 to 2008 .

the study area, there were 63 glaciers with a combined map area of $15.09 \mathrm{~km}^{2}$. Only two glaciers, IGAN and MGU, were larger than $1 \mathrm{~km}^{2}$, with $1950 \mathrm{~s}$ areas of 1.25 and $1.17 \mathrm{~km}^{2}$ respectively, while most glaciers had an area between 0.3 and $0.1 \mathrm{~km}^{2}$. Cirque (29) and niche (30) glaciers prevailed in the study area, due to the local topography and very intensive snowdrift which plays an important role in snow accumulation and glacier nourishment (Dolgushin, 1961; Troitskiy and others, 1966; Voloshina, 1988). Other types included cirque-valley (two) and hanging (two) glaciers (WGl; http:// nsidc.org/data/glacier_inventory/). Most glaciers are located west of the Ural watershed but on lee slopes, and have easterly aspects. In the 1950s-60s, glacier tongues were positioned mostly at $400-800 \mathrm{~m}$ a.s.l. The tongue of Obruchev glacier, reaching $388 \mathrm{~m}$ a.s.l., had one of the lowest elevations in the region, while the largest (IGAN) glacier descended to $835 \mathrm{~m}$ a.s.I. Despite the considerable variation in elevations of individual glaciers, there was no clear geographical pattern and the differences between the elevations of glacier tongues in the northern and southern sectors of the study region were negligible due to higher snow accumulation in the south (Troitskiy and others, 1966). The firn-line elevation, which is usually positioned close to the equilibrium-line altitude (ELA), varied between 500 and 550 m a.s.l. for Obruchev glacier, through 800-900 ma.s.l. for MGU glacier, to 900-1000 ma.s.I. for IGAN glacier (Troitskiy and Kemmerikh, 1966).

IGAN glacier is the largest in the region. In 1953 it had a surface area of $1.17 \mathrm{~km}^{2}$ (this value is based on our measurements using aerial photography and differs from the value of $1.25 \mathrm{~km}^{2}$ reported by the WGI). It is located on the slopes of Khar-Naurdy-Key mountain and consists of two sectors. A larger sector with an area of $0.73 \mathrm{~km}^{2}$ in 1953 and northeasterly aspect was classified as a cirquevalley glacier by Troitskiy and Kemmerikh (1966). A smaller sector of IGAN glacier faces east. Obruchev glacier, which measured $0.34 \mathrm{~km}^{2}$ in 1953, is located in a deep cirque and has an easterly aspect. A deep col in the western (upper) part of the glacier (Fig. 7, further below) allows penetration of westerly wind, enhancing snow accumulation (Troitskiy and others, 1966).

The high-latitude location of the region predetermines low temperatures throughout the year despite the relatively low elevations. At the nearest meteorological station at Salekhard $\left(66.53^{\circ} \mathrm{N}, 66.67^{\circ} \mathrm{E} ; 16 \mathrm{ma.s.l.}\right)$ (Fig. 1), mean monthly temperatures are positive between June and September (Fig. 2). There is a close correlation between air temperatures at Salekhard and those in the Polar Ural glacier region. The correlation coefficient between daily air temperatures at 
Salekhard and temperatures obtained by the Campbell Scientific automatic weather station installed between July 2008 and August 2009 on IGAN glacier is 0.89. The ablation season is short, lasting from the end of June to the end of August, although in individual years glacier melt extends into September (Troitskiy and others, 1966). The 1963, 1969 and 2000 ablation seasons, when glacier tongues were already free of seasonal snow by the end of June, were notable exceptions. Thus, ablation in 1963 was among the highest on record, averaging $3800 \mathrm{~mm}$ w.e. on IGAN glacier (Troitskiy and others, 1966).

The Polar Ural region is dominated by westerly flow, and depressions originating over the North Atlantic and the Barents Sea are the main source of precipitation throughout the year. The average precipitation at Salekhard is $440 \mathrm{~mm} \mathrm{a}^{-1}$. Precipitation at Bolshaya Khadata station $\left(67.61^{\circ} \mathrm{N}, 66.09^{\circ} \mathrm{E} ; 264 \mathrm{~m}\right.$ a.s.l.), which functioned close to the glacier tongues between 1958 and 1981, was $610 \mathrm{~mm} \mathrm{a}^{-1}$. The annual cycle of precipitation is characterized by a summer maximum (Fig. 2), and more than half the annual precipitation $\left(270 \mathrm{~mm} \mathrm{a}^{-1}\right.$ in the period $1970-2000$ at Salekhard) occurs between October and May as solid precipitation. The reported precipitation measurements are subject to large errors in the cold season because of both under-capture of snow by rain gauges, and frequent snowdrifts (Groisman and Rankova, 2001). The average winter balances on IGAN and Obruchev glaciers between 1958 and 1980 were 2.32 and 2.71 m w.e. respectively, and the average summer balances were -2.52 and $-2.86 \mathrm{~m}$ w.e. The region is characterized by strong interannual variability in both accumulation and ablation (Voloshina, 1988; Tsvetkov, 2006).

\section{DATA AND METHODS}

Changes in the surface area of 30 glaciers were assessed using aerial photographs acquired in 1953 and/or 1960 and the Advanced Spaceborne Thermal Emission and Reflection Radiometer (ASTER) and panchromatic Landsat Enhanced Thematic Mapper Plus (ETM+) imagery from 2000 (Table 1). Smaller-scale aerial and terrestrial photogrammetric surveys of selected glaciers were conducted by the Institute of Geography, Russian Academy of Sciences, (IGRAS) in the Polar Urals in 1968, 1973 and 1981 (Table 1). The 1973 and 1981 data were used to assess glacier changes at higher temporal resolution. The 1968 data were excluded from the analysis due to extensive snow cover that persisted till the end of the ablation season (Section 2). The lack of metadata for the aerial surveys and lack of detail in the 1981 maps did not allow us to construct DEMs from these sources. Twentyeight measured glaciers had map areas larger than $0.1 \mathrm{~km}^{2}$ in 1953 (1960), and two glaciers had areas of 0.08 and $0.09 \mathrm{~km}^{2}$ (Table 2). Glaciers smaller than $0.08 \mathrm{~km}^{2}$ were not assessed because it was difficult to distinguish between glacier ice and perennial snowpatches.

\subsection{Aerial and satellite imagery}

Thirty-six aerial photographs with a resolution of $1-3 \mathrm{~m}$ for July 1953 and August 1960 covering the southern and northern sectors of the study area respectively were obtained from the IGRAS archive (Tables 1 and 2). Aerial imagery for both years is available for IGAN, Obruchev and MGU glaciers. In both years, the imagery was cloudfree and the glacier tongues were free of seasonal snow at
Table 1. Details of imagery used for mapping and glacier surveys conducted in the Polar Urals

\begin{tabular}{|c|c|c|}
\hline Date & Type of survey & Glaciers \\
\hline 30 July 1953 & Aerial photography & 16 glaciers \\
\hline 1 Aug 1960 & Aerial photography & 17 glaciers \\
\hline Aug 1963 & Theodolite survey & IGAN, Obruchev \\
\hline 20 Aug 1968 & Aerial photography & $\begin{array}{c}\text { Obruchev, MGU, Synok, } \\
\text { Karskiy }\end{array}$ \\
\hline 31 Aug 1973 & Aerial photography & $\begin{array}{l}\text { MGG, MIIGAIK, Dolgushin, } \\
\text { Boch }\end{array}$ \\
\hline 1981 & Theodolite survey & $\begin{array}{l}\text { IGAN, Obruchev, Chernov, } \\
\text { Oleniy, Anuchin, MGU }\end{array}$ \\
\hline 14 July 2000 & ASTER & 26 glaciers \\
\hline 7 July 2000 & $\begin{array}{l}\text { Panchromatic } \\
\text { Landsat ETM+ }\end{array}$ & $\begin{array}{l}\text { IGAN, Anuchin, Oleniy and } \\
\text { Bolshoy Usinskiy }\end{array}$ \\
\hline 2005 & Pilot GPS survey & 8 glaciers \\
\hline 2008 & Field DGPS survey & $\begin{array}{c}\text { IGAN, Obruchev, Chernov, } \\
\text { MGU, Dolgushin }\end{array}$ \\
\hline
\end{tabular}

the time of surveys, so aerial photographs were suitable for mapping.

Two ASTER images (15 $\mathrm{m}$ resolution; Table 1 ) acquired under nearly cloud-free conditions were obtained from the NASA Land Processes Distributed Active Archive Center where they were orthorectified prior to the distribution using $\mathrm{PCl}$ OrthoEngine software (Lang and Welch, 1999). The images did not include IGAN, Anuchin, Oleniy and Bolshoy Usinskiy, and map areas of these glaciers were derived from an orthorectified panchromatic Landsat ETM+ image $(15 \mathrm{~m}$ resolution; path 167, row 12; Table 1). Both ASTER and panchromatic Landsat ETM+ images were supplied in Universal Transverse Mercator (UTM) zone N 41 and N 42 WGS84 projection. The accuracy of the orthorectification of both ASTER and Landsat ETM+ imagery was verified using a network of interactive ground control points (GCPs) established during the GPS ground surveys in 2005 and digital GPS (DGPS) surveys of Obruchev and IGAN glaciers in 2008. As a result of high air temperatures in May-June 2000, seasonal snow melted on glacier tongues by the end of June, making the imagery suitable for mapping.

All the Polar Ural glaciers are separate ice bodies. Even at higher elevations, snow mostly disappeared from the stable terrain surrounding the glaciers, and their upper boundaries were clearly visible on both aerial and satellite imagery.

\subsection{Glacier mapping procedures and quantification of errors}

The digitized aerial photographs from 1953, 1960 and 1973 were co-registered to the orthorectified ASTER and Landsat ETM+ images using a network of 10-15 GCPs per individual photograph and ERDAS Imagine 9.0 software. The hydrographic and topographic features on stable terrain in the vicinity of glacier termini were used as GCPs. After coregistration, root-mean-square error $\left(\mathrm{RMSE}_{x, y}\right)$ values not exceeding $5 \mathrm{~m}$ were achieved, which is less than the size of the ASTER and panchromatic Landsat ETM+ pixels. Following co-registration, glacier outlines were manually mapped on ASTER, Landsat ETM+ and aerial imagery. Human interpretation was more suitable than automatic or semiautomatic procedures for extracting detailed information from the imagery, because of the relatively small sample of 
Table 2. Glacier map areas and change statistics. Areas for the 1950s-60s are different from those listed by the WGl (http://nsidc.org/data/ glacier_inventory/). $\Delta A$ is change in map area

\begin{tabular}{|c|c|c|c|c|c|c|c|c|c|}
\hline \multirow[t]{2}{*}{ Glacier } & \multirow{2}{*}{$\begin{array}{l}1953 \\
\mathrm{~km}^{2}\end{array}$} & \multirow{2}{*}{$\begin{array}{l}1960 \\
\mathrm{~km}^{2}\end{array}$} & \multirow{2}{*}{$\begin{array}{l}1968 \\
\mathrm{~km}^{2}\end{array}$} & \multirow{2}{*}{$\begin{array}{l}1973 \\
\mathrm{~km}^{2}\end{array}$} & \multirow{2}{*}{$\begin{array}{l}1981 \\
\mathrm{~km}^{2}\end{array}$} & \multirow{2}{*}{$\begin{array}{c}2000 \\
\mathrm{~km}^{2}\end{array}$} & \multirow{2}{*}{$\begin{array}{c}2008 \\
\mathrm{~km}^{2}\end{array}$} & \multicolumn{2}{|c|}{$\Delta A(1953 / 60-2000)$} \\
\hline & & & & & & & & $\mathrm{km}^{2}$ & $\%$ \\
\hline IGAN & 1.17 & 1.11 & & & 1.06 & 0.89 & 0.74 & $0.28^{*}$ & $23.9 \pm 2.7$ \\
\hline Bolshoy Usinskiy & 0.70 & & & & & 0.67 & & $0.03 *$ & $4.3 \pm 2.6$ \\
\hline Obruchev & 0.34 & 0.33 & 0.30 & & 0.30 & 0.25 & 0.24 & $0.09 *$ & $26.5 \pm 2.7$ \\
\hline Chernov & & 0.26 & & & 0.25 & 0.16 & 0.15 & 0.10 & $38.5 \pm 3.2$ \\
\hline Berg & & 0.26 & & & & 0.24 & & 0.02 & $7.7 \pm 3.2$ \\
\hline Kovalskiy & 0.20 & & & & & 0.13 & & $0.07^{*}$ & $35.0 \pm 3.4$ \\
\hline Lepehin & 0.10 & & & & & 0.08 & & $0.02 *$ & $20.0 \pm 4.0$ \\
\hline Shumskiy & 0.17 & & & & & 0.11 & & $0.06^{*}$ & $35.3 \pm 4.1$ \\
\hline Avsyuk & 0.11 & & & & & 0.10 & & $0.01 *$ & $9.1 \pm 5.3$ \\
\hline Kalesnik & 0.18 & & & & & 0.16 & & $0.02 *$ & $11.1 \pm 3.4$ \\
\hline Khabakov & 0.12 & & & & & 0.09 & & $0.03 *$ & $25.0 \pm 5.5$ \\
\hline Skrytniy & 0.08 & & & & & 0.05 & & $0.03 *$ & $37.5 \pm 6.7$ \\
\hline Avgevych & 0.09 & & & & & 0.07 & & $0.02 *$ & $22.2 \pm 5.4$ \\
\hline Oleniy & 0.12 & & & & 0.10 & 0.10 & & $0.02 *$ & $16.7 \pm 5.2$ \\
\hline Anuchin & 0.11 & & & & 0.10 & 0.10 & & $0.01 *$ & $9.1 \pm 5.2$ \\
\hline MGU & 0.98 & 0.93 & 0.86 & & 0.78 & 0.53 & 0.45 & $0.45^{*}$ & $45.9 \pm 2.7$ \\
\hline Synok & 0.19 & & 0.19 & & & 0.12 & & $0.07^{*}$ & $36.8 \pm 3.1$ \\
\hline Karskiy & 0.60 & & 0.61 & & & 0.51 & & $0.09 *$ & $15.0 \pm 2.6$ \\
\hline Palgov & & 0.15 & & & & 0.1 & & 0.05 & $33.3 \pm 6.1$ \\
\hline Markov & & 0.19 & & & & 0.16 & & 0.03 & $15.8 \pm 3.4$ \\
\hline Malysh & & 0.13 & & & & 0.12 & & 0.01 & $7.7 \pm 4.1$ \\
\hline Fedorov & & 0.25 & & & & 0.23 & & 0.02 & $8.0 \pm 2.7$ \\
\hline Shuchiy & & 0.47 & & & & 0.37 & & 0.10 & $21.3 \pm 2.1$ \\
\hline Tronov & & 0.22 & & & & 0.20 & & 0.02 & $9.1 \pm 2.8$ \\
\hline Aleshkov & & 0.31 & & & & 0.26 & & 0.05 & $16.1 \pm 2.4$ \\
\hline Terentyev & & 0.15 & & & & 0.14 & & 0.01 & $6.7 \pm 5.6$ \\
\hline MGG & & 0.47 & & 0.46 & & 0.38 & & 0.09 & $19.1 \pm 3.3$ \\
\hline MIIGAIK & & 0.33 & & 0.30 & & 0.25 & & 0.08 & $24.2 \pm 3.3$ \\
\hline Dolgushin & & 0.67 & & 0.63 & & 0.49 & 0.46 & 0.18 & $26.9 \pm 2.8$ \\
\hline Boch & & 0.10 & & 0.10 & & 0.09 & & 0.01 & $10.0 \pm 6.2$ \\
\hline Total & & 9.17 & & & & 7.13 & & 2.04 & $22.3 \pm 3.9$ \\
\hline
\end{tabular}

*1953 is used as reference year.

glaciers and the limitations of automated techniques associated with misclassification of water bodies that are widespread in the region (Raup and others, 2007; Bolch and others, 2010). The error of co-registration of aerial photography and satellite imagery was estimated following a methodology proposed by Granshaw and Fountain (2006). A buffer, with a width of half of the RMSE ${ }_{x, y}$ determined for each aerial photograph, was created along the 1953, 1960, and 1973 and 2000 glacier outlines, and the error term was calculated as an average ratio between the original areas and the areas with a buffer increment.

Debris cover and shadows, especially from cirque walls, are the well-known sources of uncertainty in glacier mapping. Continuous debris cover is not typical of the Polar Ural glaciers, and many glaciers terminate in lakes, which simplifies terminus mapping. Two glaciers in the sample (Avsyuk and Kalesnik) have continuous debris cover on their tongues, and the MGG and MIIGAIK glacier tongues feature intermittent debris cover. These glaciers were visited during a pilot study in 2005, and the extent of debris cover was mapped using a GPS. The difference between the extent of debris cover mapped in the field and from satellite imagery did not exceed $1 \%$ of the debris-covered area. Based on this result, an additional error of $1 \%$ was assigned to both 2000 and 1953 areas of these glaciers. Where glacier margins were obscured by shadows, a contrast-stretching function was applied to the imagery using ENVI 3.5 software. The total error of glacier area change was calculated as an error of co-registration, or as a root mean square of the three error terms (co-registration and debris-cover-related error in 2000 and 2008) where applicable (Table 2).

\subsection{Ground-based surveys of 1963 and 2008}

Terrestrial theodolite surveys of IGAN and Obruchev glaciers were conducted by IGRAS on 10 and 28 August 1963 respectively. During the surveys of 1963, tongues of both glaciers were already free of seasonal snow by mid-July (Section 2) and suitable for mapping: 1:5000 scale maps of both glaciers with equidistant contours of $5 \mathrm{~m}$ were produced (Tsvetkov, 1969). Vertical precision of the 1963 maps is estimated as $\pm 2.5 \mathrm{~m}$, which is the half-distance between the contours. The maps were scanned at $600 \mathrm{dpi}$ resolution and the contours were digitized manually with an accuracy of $\pm 0.2 \mathrm{~mm}$ which is $\pm 1 \mathrm{~m}$ in ground distance. The maps were transformed to UTM zone N 41 (Obruchev) and zone N 42 (IGAN) on the WGS84 projection using ArcGIS 9.2. Coordinates of GCPs established in 1963 and of notable topographic features located in the vicinity of Obruchev and IGAN glaciers during the 2008 DGPS survey were used for georeferencing.

DGPS surveys of IGAN, Obruchev, Chernov, MGU and Dolgushin glaciers were conducted between 28 July (IGAN) 
and 11 August (Obruchev) 2008 using Topcon Hiper Pro DGPS. Boundaries of all four glaciers were mapped, and surface elevation measurements were taken at Obruchev and IGAN glaciers. Only the northeast-facing sector of IGAN was surveyed because the state of the surface of the south-facing sector limited access. Therefore, the geodetic mass balance of IGAN glacier reported here refers to its northeast (larger) sector, while glaciological mass balances reported in earlier publications refer to the whole glacier. Surface elevation measurements were taken at the points of a quasi-regular grid with a $40 \mathrm{~m}$ mesh, with the total number of points being 430 and 218 for IGAN and Obruchev glaciers respectively. The glacier tongues were mainly free of seasonal snow at the time of the 2008 survey. However, at the 1963 snowline position the thickness of seasonal snow averaged $0.4 \mathrm{~m}$ on IGAN glacier (975 m a.s.I.) and $0.9 \mathrm{~m}$ on Obruchev glacier (550 m a.s.I.). Details of the 1963 snow depth surveys were available from the IGRAS archive (unpublished field records), and in 2008 the seasonal snow thickness was measured on both glaciers along the 1963 profiles for the subsequent correction of DEMs for seasonal snow cover.

Coordinates (longitude and latitude; $x$ and $y$ ) and elevations $(z)$ of the GCPs were measured with an accuracy of $\pm 0.07 \mathrm{~m}(x, y)$ and $\pm 0.1 \mathrm{~m}(z)$. In areas closer to cirque walls in the accumulation zones, the accuracy dropped to $\pm 0.15 \mathrm{~m}(x, y)$ and $\pm 0.2 \mathrm{~m}(z)$. The glacier boundaries in the upper part of the accumulation zone remained unchanged on most glaciers since 1953/60 because avalanche nourishment dominates in these areas. The position of snow mass delivered by avalanches remained the same as in previous years, as shown by the aerial and historical ground-based photography. However, there are exceptions where the upper boundary receded, as on the smaller sector of IGAN and on MGU glacier.

\subsection{Calculation of geodetic mass balance and volume changes}

DEMs of IGAN and Obruchev glaciers with 5.5 and $3.5 \mathrm{~m}$ resolution respectively were derived from the digitized 1963 topographic maps and the 2008 DGPS survey data, using the ArcGIS 9.2 triangular irregular network (TIN) method. Coordinates and elevations of the GCPs established on stable terrain both in 1963 and in 2008 were used as tie points for co-registration and relative control of the 1963 and 2008 DEMs. Volume changes were calculated for the common glacier areas covered by the 1963 and 2008 DEMs, and the volume of the completely melted ice mass was inferred from the 1963 DEM. Geodetic mass balance was calculated following Fischer (2011) as a product of volume change and average ice density. Specific mass balance was calculated by dividing the value of geodetic mass balance by the average (1963 and 2008) glacier area following Thibert and others (2008).

Information about ice density is required to convert changes in glacier surface elevation into a mass change. Most geodetic mass-balance calculations assume that changes in elevation are due to the loss of ice with a constant density of $900 \mathrm{~kg} \mathrm{~m}^{-3}$ (e.g. Andreassen, 1999; Arendt and others, 2002; Cogley, 2009). Zemp and others (2010) commented that this assumption often leads to an overestimation of mass balance and recommended the use of an average of minimum and maximum assumptions on ice and firn densities. In their calculation of Storglaciären (Sweden) geodetic mass balance, Zemp and others (2010) used an average density of $860 \mathrm{~kg} \mathrm{~m}^{-3}$ and applied a difference between the maximum and minimum estimates of $60 \mathrm{~kg} \mathrm{~m}^{-3}$ as an uncertainty measure. Ice density measurements were conducted annually on IGAN and Obruchev glaciers between 1959 and 1963, providing an average value of $840 \mathrm{~kg} \mathrm{~m}^{-3}$ (Khodakov, 1966). More recent three-dimensional measurements are not available and we used a value of $840 \mathrm{~kg} \mathrm{~m}^{-3}$ with an uncertainty term of $\pm 60 \mathrm{~kg} \mathrm{~m}^{-3}$.

\subsection{Quantification of errors in geodetic mass balance and volume changes}

Errors in the calculation of changes in glacier volume and geodetic mass balance result from errors in the constructed DEMs and, in case of mass balance, uncertainty of ice density measurements or assumptions. The probable sources of errors in DEMs are (1) uncertainties of maps and surveys used in DEM construction; (2) accuracy of map digitizing; (3) interpolation on a grid during DEM construction, especially if glacier topography is complex and is characterized by steep slopes; and (4) seasonality in thickness change (Sapiano and others, 1998; Andreassen, 1999; Arendt and others, 2002; Thibert and others 2008; Koblet and others, 2010). Evaluations of DEM accuracy vary between complex and comprehensive error propagation analyses (e.g. Thibert and others, 2008), assessments based on a comparison of the DEM values with an independent set of GCPs located in non-glaciated terrain (e.g. Koblet and others, 2010), and relative errors between two or more DEMs over the bedrock (e.g. Cox and March, 2004). The latter method is frequently used because relative errors and consistency between the historical and recent DEMs are more important for the calculation of geodetic mass balance than absolute elevations (Cox and March, 2004; Thibert and others, 2008).

In our assessment of errors, we considered (1) error in elevation change; (2) planimetric error of the calculated glacier areas; (3) uncertainty in assumptions about ice density; and (4) uncertainty due to the seasonality of thickness change related to the seasonal snow cover. To correct for changes in seasonal snow cover, the 2008 DEM was corrected relative to the 1963 DEM using the 1963 and 2008 snow depth measurements. To quantify errors in elevation change, the 2008 DEM was subtracted from the 1963 DEM over the ice-free stable terrain, producing $\mathrm{RMSE}_{z}$ of $\pm 2.1 \mathrm{~m}$ and $\pm 1.7 \mathrm{~m}$ for IGAN and Obruchev glaciers respectively $(14 \%$ and $7.5 \%$ of the observed average glacier surface lowering). Relative errors are often higher over the bedrock than over glacier areas because of a less dense network of points (Cox and March, 2004; Koblet and others, 2010) and it is likely that this error term is overestimated in this study.

The planimetric error terms included (1) accuracy of DGPS measurements taken as the lowest accuracy obtained in the parts of the glacier with a weak satellite signal $( \pm 0.15 \mathrm{~m})$; (2) error of the 1963 map digitizing $( \pm 1.0 \mathrm{~m})$; and (3) accuracy of triangulation and DEM construction represented by $\operatorname{RMSE}_{x, y}( \pm 4.5 \mathrm{~m}$ and $\pm 5.0 \mathrm{~m}$ for IGAN and Obruchev glaciers respectively). The total planimetric errors were $\pm 4.6 \mathrm{~m}$ and $\pm 5.1 \mathrm{~m}$ for IGAN and Obruchev glaciers respectively, or $3.3 \%$ and $4.7 \%$ of their areas. We have not included an error term for the delineation of glacier boundaries, as these were very clearly defined both in 1963 and 2008 in the absence of seasonal snow and debris cover on the glacier tongues. 


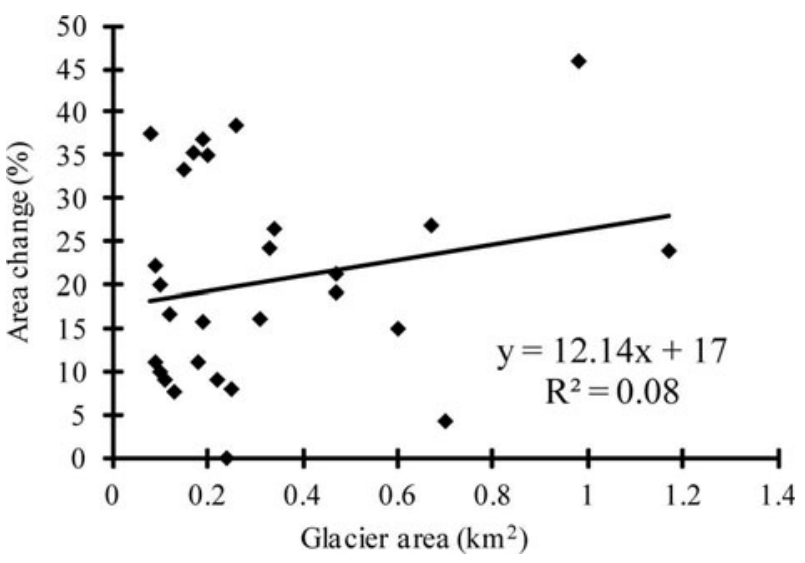

Fig. 3. Change in glacier area between $1953 / 60$ and 2000 versus individual glacier area (as in 1953/60).

\section{RESULTS}

\subsection{Changes in area of 30 glaciers since $1953 / 60$}

Analysis of the satellite imagery has shown that in 2000 there were 30 glaciers in the study region with a combined map area of $7.13 \pm 0.2 \mathrm{~km}^{2}$. This represents a net area reduction of $2.04 \pm 0.08 \mathrm{~km}^{2}$ from 1953/60 (Table 2). Overall, the Polar Ural glaciers have lost $22.3 \pm 3.9 \%$ of their $1953 / 60$ area, but the extent of shrinkage varies significantly, between 4\% (Bolshoy Usinskiy glacier) and 46\% (MGU glacier). Ten glaciers have lost not less than $25 \%$ of their area over 40 (47) years. The two largest glaciers in the region, IGAN (both sectors are included in the planimetric measurements) and MGU, were classified by the WGI as cirquevalley. They exhibited the highest absolute and relative loss of area, averaging $34.9 \pm 2.7 \%$. The cirque glaciers have lost $20 \pm 3.9 \%$ of their $1953 / 60$ area while niche glaciers have lost $14 \pm 4.1 \%$. The difference in the rates of shrinkage of cirque and niche glaciers may reflect the topographically favourable, shaded locations of the niche glaciers. Seventeen out of thirty glaciers in the study area have easterly aspect and these glaciers have lost $22.4 \pm 3.9 \%$ of their area. Glaciers with northerly (four), northeasterly (six) and southeasterly (three) aspects have lost $20.3 \pm 3.3 \%, 16.1 \pm 4 \%$ and $17.6 \pm 2.8 \%$ respectively. The difference between the shrinkage rates of glaciers with different aspects is small and close to the accuracy of area change measurements in this dataset. Similarly, correlation between glacier size and area reduction is weak in the study region, possibly due to the small range of individual glacier areas (Fig. 3). Although changes in area of glaciers smaller than $0.08 \mathrm{~km}^{2}$ in 1953/60 were not quantified, it was noted that some of these very small glaciers (e.g. Baklund and Kulik) had melted completely and had been replaced by lakes by 2000 .

The ground-based surveys, conducted in 1981 and 2008, enabled a comparison of changes in the rates of area loss of IGAN, MGU, Chernov, Obruchev and Dolgushin glaciers (Table 2; Fig. 4). For IGAN glacier this accelerated fourfold in the last two decades of the 20th century. Between 1953 and 1981 , IGAN glacier lost on average $0.2 \%$ of its area per year $(9.4 \%$ of the 1953 area overall); between 1981 and 2008 , it lost on average $1.1 \%$ of 1981 area per year $(30.2 \%$ of the 1981 area overall). The rate of area reduction of MGU glacier in the 1953-81 period was the highest of any glacier in the study region (Tsvetkov, 2006), and our analysis confirms that this glacier exhibited the strongest shrinkage
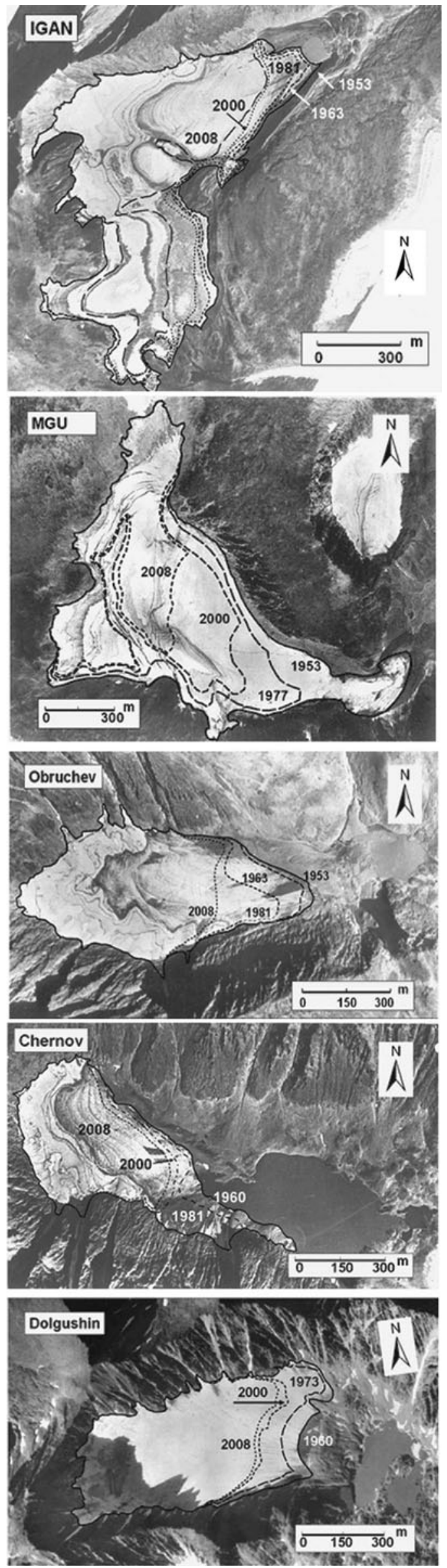

Fig. 4. Changes in map areas of the five largest glaciers of the Polar Urals between 1953 and 2008. Aerial photographs from 1953 (1960 for Chernov and Dolgushin glaciers) are used as background. 

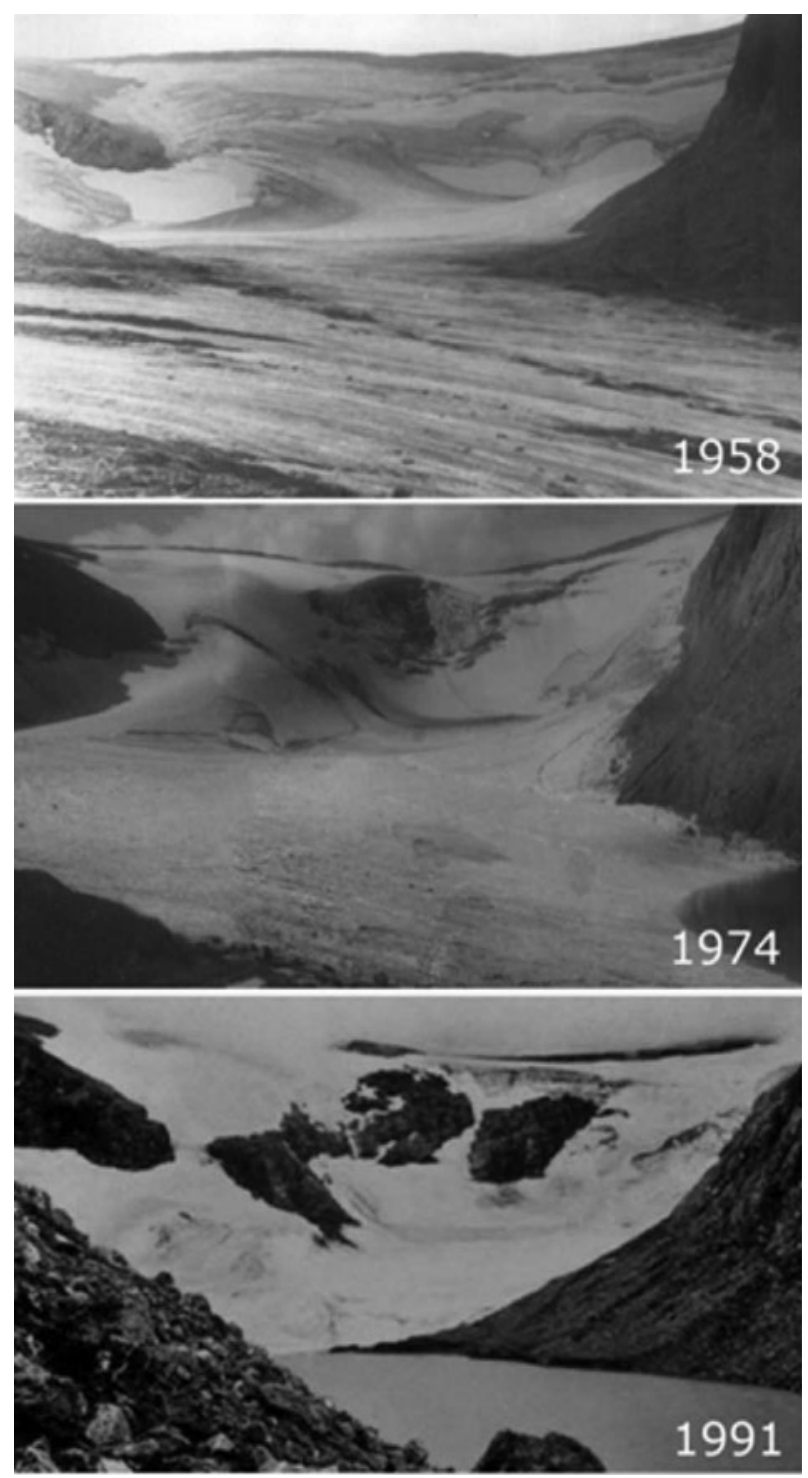

Fig. 5. Repeated ground-based photographs of MGU glacier in 1958, 1974 and 1991. Strong glacier wastage occurred between 1974 and 1991 with the formation of a contact lake.

(Table 2). The glacier snout receded so rapidly that Tsvetkov and Tyuflin (1981) recognized that the glacier should be reclassified as a cirque glacier. The repeat photography (Fig. 5), featuring formation of a proglacial lake, illustrates the acceleration of MGU glacier recession in the 1974-91 period relative to $1958-74$. The rate of map area reduction of MGU glacier doubled from $0.7 \% \mathrm{a}^{-1}(1953-81)$ to $1.5 \% \mathrm{a}^{-1}$ (1981-2008). In addition to a $46 \%$ loss of its

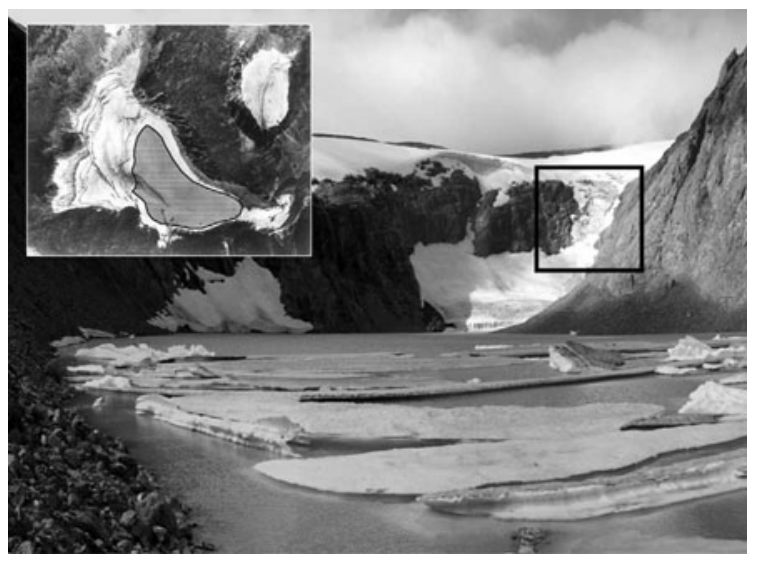

Fig. 6. MGU glacier in 2008. The inset image shows the extent of the lake in 2008 relative to the glacier size in 1953. Rectangle shows the area where separation between the glacier tongue and the accumulation zone is likely to occur.

1953 area in the 1953-2000 period (Table 2), the glacier lost a further $16 \%$ of its 2000 area in 2008 . The proglacial lake, formed in the 1980s, occupied 28\% of the 1953 MGU glacier area in 2008 (Fig. 6). Chernov glacier, which lost $38.6 \%$ of its area between 1960 and 2000, is among the fastest-receding glaciers in the region (Table 2). Most of the wastage occurred after 1981, reaching $1.9 \% \mathrm{a}^{-1}$ between 1981 and 2000. The overall loss of map area by Obruchev glacier was lower, at 26\% between 1953 and 2000 (Table 2), but its area reduction accelerated from $0.4 \% \mathrm{a}^{-1}$ in the 1953-81 period to $0.7 \% \mathrm{a}^{-1}$ between 1981 and 2008 . Repeat ground-based photographs from 1963 and 2005 illustrate a more subdued retreat of Obruchev glacier (Fig. 7). Between 1968 and 1981, it did not exhibit measurable changes in its area (Table 2), and a small increase occurred from $0.29 \mathrm{~km}^{2}$ in 1963 to $0.30 \mathrm{~km}^{2}$ in 1968. Although this change was small and close to the accuracy of measurements, the glaciological mass-balance data (Voloshina, 1988) confirm that Obruchev gained mass briefly in the 1960s.

\subsection{Changes in volume and geodetic mass balance on IGAN and Obruchev glaciers}

Changes in characteristics of IGAN and Obruchev glaciers are shown in Table 3. Obruchev glacier, positioned at lower elevations, experienced stronger downwasting at an average rate of $0.5 \mathrm{~m} \mathrm{a}^{-1}$ between 1963 and 2008. As expected, the largest changes occurred on the glacier tongue, where surface lowering exceeded 40-50 m (Fig. 8). The field survey data from the 1960s to the 1970s indicated that ice thickness

Table 3. Changes in characteristics of Obruchev glacier and northeastern sector of IGAN glacier between 1963 and 2008

\begin{tabular}{|c|c|c|c|c|c|}
\hline \multirow[t]{2}{*}{ Glacier } & Map area reduction & Average surface lowering & Max surface lowering & Volume reduction & $\begin{array}{c}\text { Cumulative area-weighted } \\
\text { mass balance }\end{array}$ \\
\hline & $\mathrm{km}^{2}$ & $\mathrm{~m}$ & $\mathrm{~m}$ & $10^{6} \mathrm{~m}^{3}$ & mw.e. \\
\hline Obruchev* & $0.049 \pm 0.002$ & $22.5 \pm 1.7$ & $63.4 \pm 1.7$ & $6.55 \pm 0.8$ & $-20.66 \pm 2.91$ \\
\hline $\mathrm{IGAN}^{\dagger}$ & $0.12 \pm 0.006$ & $14.9 \pm 2.1$ & $48.3 \pm 2.1$ & $10.14 \pm 1.8$ & $-13.54 \pm 2.57$ \\
\hline
\end{tabular}

*A difference in area change of Obruchev glacier between Tables 2 and 3 is due to a $0.01 \mathrm{~km}^{2}$ increase in glacier area between 1963 and 1968 (Section 4.1 ).

${ }^{\dagger}$ Changes in the northeastern sector of IGAN only, whereas Table 2 shows changes in the whole of IGAN glacier. 

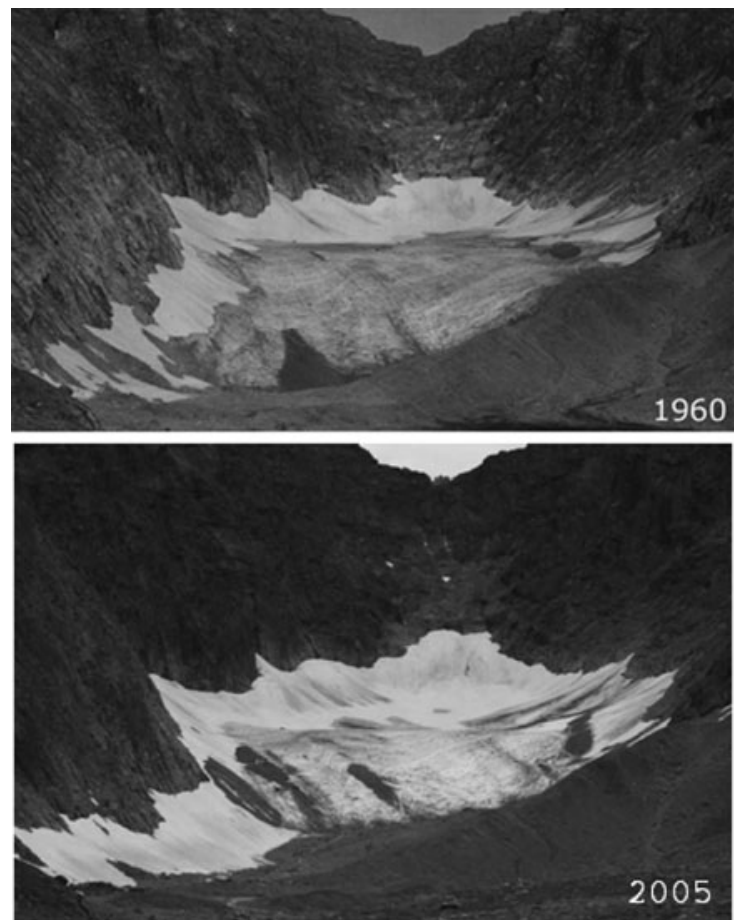

Fig. 7. Repeated ground-based photographs of Obruchev glacier in 1960 and 2005.

did not exceed 15-25 $\mathrm{m}$ on the glacier snout, as a result of intensive downwasting observed between 1953 and 1966 (Macheret and Zhuravlev, 1981), hence this ice was entirely lost. Glacier downwasting was not limited to the ablation zone, and, even on the upper part of the accumulation zone, glacier thinning reached $30 \mathrm{~m}$ (Fig. 8). Overall, the glacier lost $(6.55 \pm 0.8) \times 10^{6} \mathrm{~m}^{3}$ of ice between 1963 and 2008 . The cumulative area-weighted mass balance of Obruchev glacier for the 1963-2008 period was $-20.66 \pm 2.91 \mathrm{~m}$ w.e., and the average mass balance was $-460 \pm 65 \mathrm{~mm}$ w.e. $\mathrm{a}^{-1}$.

Downwasting of the northeastern sector of IGAN glacier, whose snout is positioned $\sim 400 \mathrm{~m}$ higher than the snout of Obruchev glacier, was more subdued (Fig. 9). While surface lowering exceeded $40 \mathrm{~m}$ on IGAN's snout, thickness loss did not exceed $10 \mathrm{~m}$ in the lower part of the accumulation zone and was within the error margin in its upper part. Overall, the glacier lost $(10.14 \pm 1.8) \times 10^{6} \mathrm{~m}^{3}$ of ice between 1963 and 2008. The cumulative area-weighted mass balance of IGAN glacier for the 1963-2008 period was $-13.54 \pm 2.57 \mathrm{~m}$ w.e., and the average mass balance was $-300 \pm 57 \mathrm{~mm}$ w.e. $\mathrm{a}^{-1}$.

\section{DISCUSSION}

\subsection{Rates of glacier change}

By the beginning of the 21 st century, glaciers of the Polar Urals had lost $22.3 \pm 3.9 \%$ of their area since $1953 / 60$. The use of two reference years (1953 and 1960) should be noted when comparing wastage rates of individual glaciers. Thus IGAN, MGU and Obruchev glaciers, for which both 1953 and 1960 measurements are available, lost $4.8 \%$ of their combined area between 1953 and 1960, but while the shrinkage rate of $0.7 \% \mathrm{a}^{-1}$ is not negligible, the overall reduction is comparable with error terms in the calculation of glacier shrinkage between the reference years and 2000.

For seven out of thirty glaciers, the area loss exceeded $30 \%$ (Table 2). Five of these seven terminate in lakes and this a

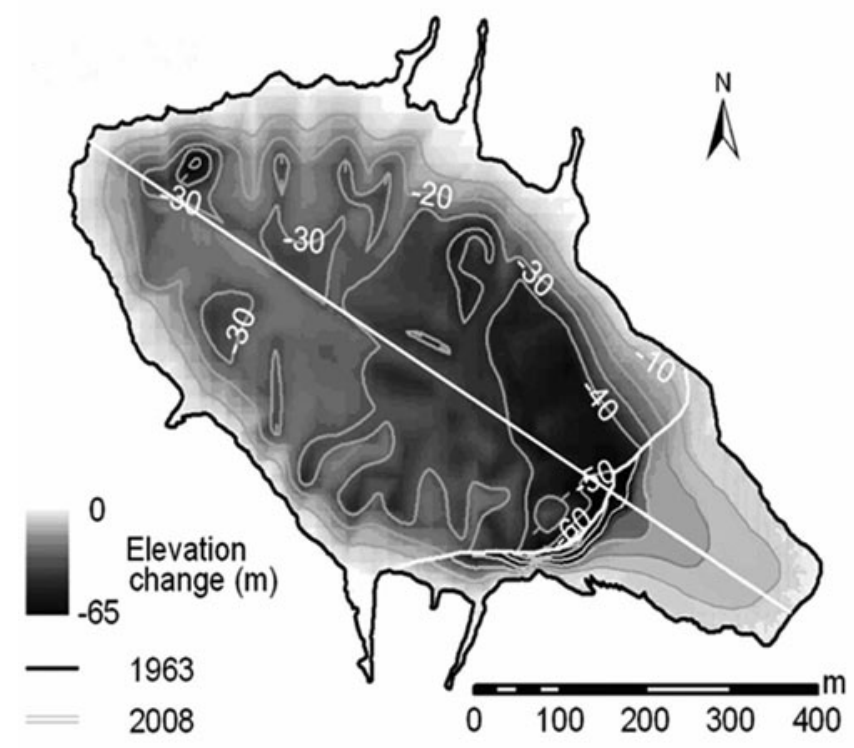

b

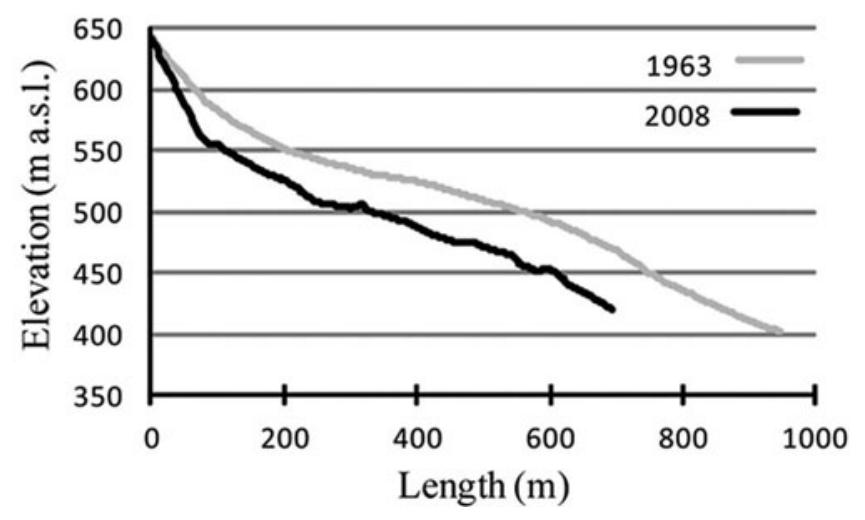

Fig. 8. (a) Changes in surface elevation of Obruchev glacier between 1963 and 2008, and (b) profiles of the surface elevations in 1963 and 2008. Solid straight line in (a) shows location of the profiles.

factor may have enhanced their wastage. The topography of the Polar Urals favours the formation of lakes, and their development is perhaps more widespread than in other glaciated regions. Glacier shrinkage accelerated towards the end of the 20th century. Thus the combined areas of IGAN, Obruchev and MGU glaciers declined by $14 \%$ in the $1953-$ 81 period and by $33 \%$ in 1981-2008. Overall, these glaciers lost $42.6 \%$ of their combined 1953 area; MGU glacier lost $46 \%$ of its 1953 area by 2000 (Table 2) and 54\% by 2008 . Obruchev glacier lost $26.5 \%$ of its area by 2000 (29\% by 2008). A very rapid reduction in Obruchev's area occurred in the early 1960s, when it declined from $0.33 \mathrm{~km}^{2}$ in 1960 (Table 2) to $0.29 \mathrm{~km}^{2}$ in 1963 as indicated by the field survey data, i.e. at a rate of $4 \% \mathrm{a}^{-1}$. Obruchev glacier is positioned at low elevations, and spans a small range of altitudes (410-650 ma.s.I.; Fig. 8), which is likely to be the factor explaining its rapid recession between 1953 and 1963 . Figure 7 shows that the glacier margin has retreated into the shaded cirque, and it is the combination of shading and snowdrift enhanced by local topography that is likely to have slowed glacier shrinkage. 
a

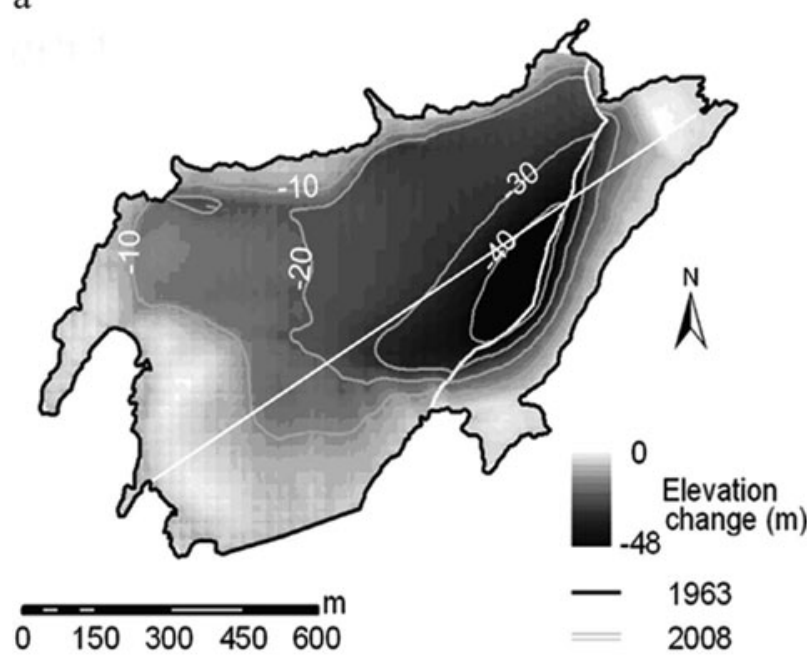

b

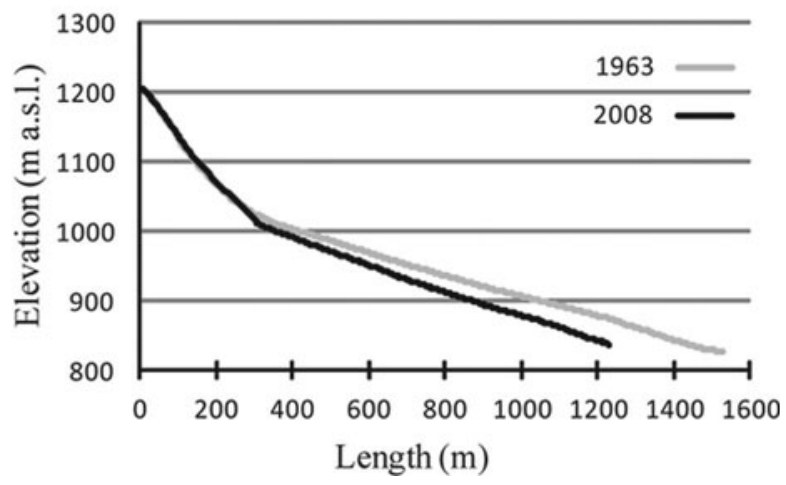

Fig. 9. Same as Figure 8, but for the northeastern sector of IGAN glacier.

Table 4 compares changes in the annual rates of glacier shrinkage in the last two decades of the 20th century and the first decade of the 21 st century for five glaciers. Three glaciers exhibited a deceleration in relative loss of area. The annual shrinkage rate decreased by over a factor of two for Chernov glacier, which lost contact with its proglacial lake in 2005. MGU and IGAN glaciers receded at a greater annual rate in the 2000-08 period than in 1981-2000, but this increase was very small for MGU glacier. These trends are consistent with an increase in the accumulation season precipitation (Section 5.2) and the increased shelter afforded by cirque headwalls as tongues are lost. The sheltering is less efficient in the case of IGAN glacier, which still has a welldefined glacier tongue and continues to recede at a higher rate. These topographic factors, protecting the cirque glaciers today, are considered by Mangerud and others (2008) as a negative feedback limiting glacier growth in the Polar Urals during the Last Glacial Maximum: the lack of shading affecting glaciers as they extended further from their cirques restricted their growth because the ELA on the glaciers of the Polar Urals is located below the climatic snowline position (Troitskiy and others, 1966).

We were not able to quantify the thinning of MGU glacier; however, repeat photography reveals strong downwasting which was already evident between 1953 and 1974 when the first exposed rocks appeared in the central section of the accumulation area (Fig. 5). Between 1974 and 1991, downwasting intensified as shown by the larger area of the
Table 4. Annual area loss for five glaciers in the 1981-2000 (19732000 for Dolgushin glacier) and 2000-08 periods

\begin{tabular}{lllll}
\hline Glacier & \multicolumn{2}{c}{$1981(1973)-2000$} & \multicolumn{2}{c}{$2000-08$} \\
& $\mathrm{~km}^{2} \mathrm{a}^{-1}$ & $\% \mathrm{a}^{-1}$ & $\mathrm{~km}^{2} \mathrm{a}^{-1}$ & $\% \mathrm{a}^{-1}$ \\
\hline IGAN & 0.00895 & 0.84 & 0.01875 & 2.11 \\
Obruchev & 0.00263 & 0.88 & 0.00125 & 0.5 \\
Chernov & 0.00474 & 1.89 & 0.00125 & 0.78 \\
MGU & 0.01316 & 1.69 & 0.01000 & 1.89 \\
Dolgushin & 0.005185 & 0.82 & 0.00375 & 0.77 \\
& & & & \\
\hline
\end{tabular}

exposed rocks (Fig. 5). In 2000, rock outcrops occupied 8\% of the 1953 glacier area. A contact lake formed in the early 1980s, and in 2008 it occupied 28\% of the 1953 glacier area (Fig. 6). MGU glacier exhibited the strongest shrinkage in the assessed sample of glaciers (Table 2) and it is likely that both the lake and the exposed rocks enhance its disintegration through the supply of extra heat to the glacier margins. The growing area of rock outcrops and exposed bedrock narrowed the central sector of the glacier to just under $120 \mathrm{~m}$ (Fig. 6), limiting the mass flux, and it is likely that in the near future the glacier tongue will be separated from the accumulation area. Similar disintegration occurred on Karskiy glacier, located close to MGU. The expansion of rock outcrops on a steep slope connecting the glacier tongue with the larger cirque sector of the glacier positioned at higher elevations led to the loss of the entire glacier tongue in the late 1990s. Strong glacier downwasting and disintegration enhanced by the expansion of lakes and rock outcrops in the Swiss Alps are discussed by Paul and others (2007). In the Polar Urals, separation of glacier sections by rock outcrops appears to be less widespread because most glaciers are positioned in cirques.

A strong surface lowering averaging $22 \mathrm{~m}$ (Table 3) and extending across the glacier including the accumulation zone was observed on Obruchev glacier, while the downwasting of IGAN glacier positioned at higher elevations was weaker. The maximum ice thickness of Obruchev glacier reached $120 \mathrm{~m}$ in 1974 (Macheret and Zhuravlev, 1981), and the observed surface lowering of $20-30 \mathrm{~m}$ in its accumulation zone (Fig. 8) implies that the glacier had lost $15-25 \%$ of its depth in the accumulation zone by 2008 . The mass balance of Obruchev glacier was $-460 \mathrm{~mm}$ w.e. $\mathrm{a}^{-1}$. The mass balance for the northeastern sector of IGAN glacier, positioned at higher elevations, was falling at a rate of $300 \mathrm{~mm}$ w.e. $\mathrm{a}^{-1}$. Combined with data on area change, the mass-balance values show that cirque glaciers such as Obruchev lose mass mainly through downwasting. As for IGAN, its mass-balance measurement would likely have been more strongly negative had we been able to include its smaller east-facing sector. While we were not able to quantify changes in surface lowering of this sector, we observed strong fragmentation of the glacier surface and the emergence of rock outcrops characteristic of downwasting.

\subsection{Comparison with other regions and climatic causes}

The observed changes and intensification of wastage in the last two decades of the 20th century are consistent with the observed shrinkage of small glaciers in northern Asia, while rates of glacier shrinkage in Scandinavia have been lower 
a

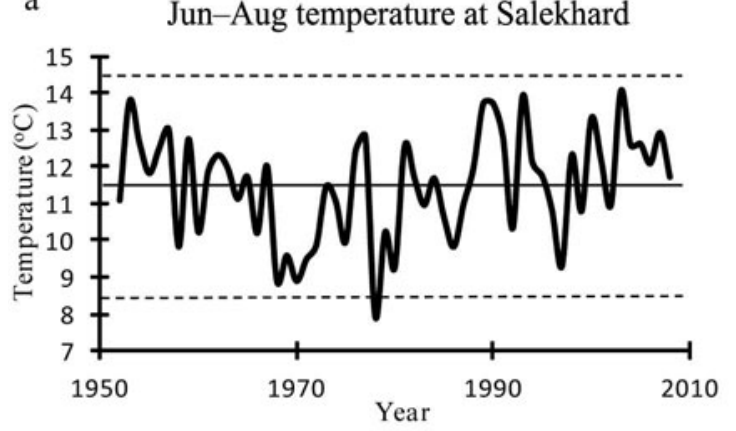

b

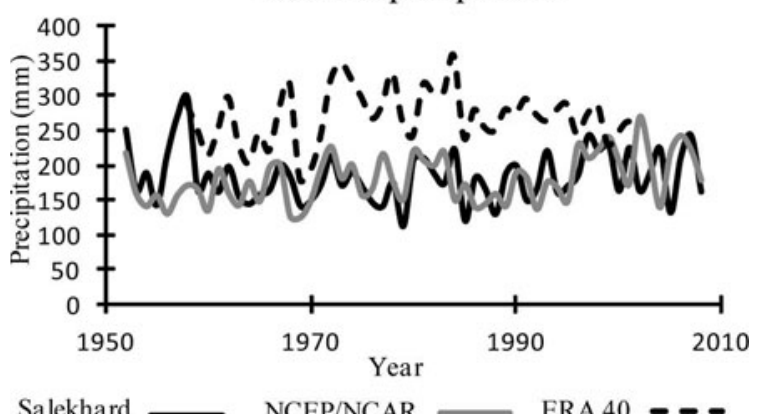

Fig. 10. Air-temperature (a) and precipitation time series (b) from Salekhard meteorological station (Fig. 1), and reanalysis data averaged over the $66-69^{\circ} \mathrm{N}, 63-67^{\circ} \mathrm{E}$ region. Straight solid and dashed lines in (a) show 1952-2008 average air temperature and \pm two standard deviations respectively.

(Andreassen and others, 2008; Paul and Andreassen, 2009; Koblet and others, 2010). Thus, small $\left(0.5-1 \mathrm{~km}^{2}\right)$ glaciers in the Altai mountains, southern Siberia, lost $28 \pm 6 \%$ of their area between 1952 and 2004 (Shahgedanova and others, 2010), and those in the Suntar-Khayata mountains, northeastern Siberia, lost 19\% between 1945 and 2003 following a $\sim 1.9^{\circ} \mathrm{C}$ increase in summer temperature (Takahashi and others, 2011). The small glaciers of the Byrranga mountains (northern Taimyr peninsula) lost 17\% between 1967 and 2003 (Kononov and Ananicheva, 2010).

While in these three regions glaciers develop under different topographic conditions, the similar wastage rates point to a uniform climatic forcing. Between the mid-1980s and the first decade of the 21 st century, summer temperatures in northern Asia increased by $1-1.5^{\circ} \mathrm{C}$ (Shahgedanova and others, 2010, 2011). Similar trends are confirmed by the climatic records from Salekhard station located in relative proximity to the glaciers of the Polar Urals (Fig. 10a). Thus, at Salekhard station the June-August mean temperature was $10.9^{\circ} \mathrm{C}$ between 1953 and 1981 , and $11.9^{\circ} \mathrm{C}$ between 1981 and 2008. The 1953-81 period was not uniform with regard to glacier shrinkage rates, which appear to closely follow temperature fluctuations, with a strong retreat in the early 1960s in the Polar Urals (Tsvetkov, 2006). The average summer temperature in $1953-68$ was $11.7^{\circ} \mathrm{C}$, while the 1970-79 decade was cold, with an average summer temperature of $10.1^{\circ} \mathrm{C}$. Solomina and others (2010) report that the pre-1900 glacier fluctuations in the Polar Urals were synchronous with summer temperature fluctuations reconstructed from lichenometry and dendrochronology.

Changes in the accumulation season precipitation are more difficult to assess due to uncertainties in both precipitation measurements (Groisman and Rankova,
2001) and reanalysis data. The October-March precipitation records from Salekhard station (Fig. 10b) and Pechora station (not shown), located southwest of the study area $\left(65.12^{\circ} \mathrm{N}\right.$, $\left.57.1^{\circ} \mathrm{E}\right)$, do not exhibit significant linear trends since 1953. The Salekhard record shows that average accumulation season precipitation in the $1984-95$ period $(170 \mathrm{~mm})$ was lower than in 1996-2008 (200 mm), but does not reveal statistically significant differences with the earlier years. The US National Centers for Environmental Prediction (NCEP)/ US National Center for Atmospheric Research (NCAR) reanalysis data (Kalnay and others, 1996) averaged over the $66-69^{\circ} \mathrm{N}, 63-67^{\circ} \mathrm{E}$ region and the $1952-2008$ period shows a positive trend in October-March precipitation explaining $16 \%$ of the total variance. According to this dataset, the 1984-95 decade (when glacier wastage intensified) had the lowest winter precipitation on record, with an average accumulation season precipitation of $160 \mathrm{~mm}$. This was significantly lower than in the 1973-84 decade, when accumulation season precipitation averaged $195 \mathrm{~mm}$ and glacier wastage slowed. However, in the 19962008 period, accumulation season precipitation increased to $200 \mathrm{~mm}$, and some glacier shrinkage rates declined (Table 4) although the general trend of glacier wastage continued. Precipitation totals retrieved from the European Centre for Medium-range Weather Forecasts ERA-40 reanalysis data (Uppala and others, 2005) averaged over the 1957-2002 period (restricted by ERA-40 data availability) significantly exceed the Salekhard and NCEP/NCAR accumulation season totals (Fig. 10b); however, these data also confirm that the 1973-84 decade was characterized by higher snowfall than the 1984-95 decade. Bulygina and others (2009) report a significant increase in various measures of snow accumulation in the Polar Urals between 1966 and 2007 including mean and maximum snow depth and number of days with snow cover exceeding $0.2 \mathrm{~m}$.

It may therefore be suggested that in the 1970s to early 1980s a combination of higher accumulation-season precipitation and lower summer temperatures contributed to a relatively slow glacier recession, while in 1984-95 positive trends in summer temperature and negative anomalies in accumulation season precipitation resulted in intensified glacier shrinkage. The accumulation season precipitation increase observed in the region since 1996 slowed glacier shrinkage compared with 1981-2000 but did not fully compensate for the effect of higher summer temperatures. In the Polar Urals, the impact of winter precipitation on glacier mass balance is strongly affected by local conditions due to high wind speeds and snowdrifting (Troitskiy and others, 1966; Voloshina, 1988). Solomina and co-workers (personal communication from IGRAS, 2011) also observed that the pre-20th-century glacier fluctuations showed little correlation with changes in precipitation. It therefore appears that the late-20th-century glacier change in the Polar Urals region is forced by an increase in summer temperature, as in other glacierized regions of northern Asia (excluding the Pacific), despite an increase in winter precipitation which was more pronounced than elsewhere in northern Asia in the last decade.

\section{CONCLUSIONS}

Changes in the area of 30 very small glaciers in the Polar Urals have been quantified, showing that these glaciers lost $22.3 \%$ of their total area between the mid-20th century and 
the beginning of the 21 st century. The observed glacier shrinkage intensified in 1981-2000 compared with the 1953-81 period. Area-weighted geodetic mass balances of two glaciers, IGAN and Obruchev, in the 1963-2008 period were calculated as $-13.54 \pm 2.57 \mathrm{mw}$.e. and $-20.66 \pm 2.91$ mw.e. respectively. It has been noted in many previous publications that the strong influence of topographic and local meteorological conditions on small glaciers makes it difficult to interpret changes in their size and thickness in the context of climate change. Indeed, glacier area loss varied strongly within the studied sample, from $4 \%$ to $46 \%$, and in some cases local factors enhancing or limiting this were identified. Data for only five glaciers were available to assess changes in glacier shrinkage rates in the first decade of the 21st century, when climatic warming intensified. These data suggest that a combination of increasing cold-season precipitation and changes in glacier morphology resulting in greater shading effects slowed glacier shrinkage in 2000-08 compared with 1981(1973)2000 but did not fully compensate for the effects of summer warming. The observed changes in summer temperature and glacier area in the Polar Urals since the mid-20th century are consistent with other regions of northern Asia excluding the Pacific. This leads us to a cautious suggestion that a common climate forcing of a $1.0-1.9^{\circ} \mathrm{C}$ increase in the ablation season temperature is responsible for the $\sim 20 \%$ loss in area of very small $\left(<1 \mathrm{~km}^{2}\right)$ glaciers in northern Asia from the mid-20th to early 21 st century.

\section{ACKNOWLEDGEMENTS}

This project was supported by a grant from the National Geographic Committee for Research and Exploration and the Russian Foundation for Basic Research. We are grateful to the reviewers, I.S. Evans and H. Escher-Vetter, for helpful comments.

\section{REFERENCES}

Abermann J, Kuhn M and Fischer A (2011) Climatic controls of glacier distribution and glacier changes in Austria. Ann. Glaciol., 52(59), 83-90 (doi: 10.3189/172756411799096222)

Aleshkov NA (1935) Gora Sablya i ee ledniki [Mount Sablya and its glaciers]. Trudy Lednik. Exped., 4, 56-74

Andreassen LM (1999) Comparing traditional mass balance measurements with long-term volume change extracted from topographical maps: a case study of Storbreen glacier in Jotunheimen, Norway, for the period 1940-1997. Geogr. Ann., 81A(4), 467-476

Andreassen LM, Paul F, Kääb A and Hausberg JE (2008) Landsatderived glacier inventory for Jotunheimen, Norway, and deduced glacier changes since the 1930s. Cryosphere, 2(2), 131-145

Arendt AA, Echelmeyer KA, Harrison WD, Lingle CS and Valentine VB (2002) Rapid wastage of Alaska glaciers and their contribution to rising sea level. Science, 297(5580), 382-386 (doi: 10.1126/science.1072497)

Bedford D and Haggerty C (1996) New digitized glacier inventory for the former Soviet Union and China. Earth Syst. Monitor, 6(3), $8-10$

Boch SG (1935) Geomofologicheskii ocherk raiona gory Narodnoi [Geomorphological description of the Mount Narodnaya region]. Trudy Lednik. Exped., 4, 118-140

Bolch T, Menounos B and Wheate R (2010) Landsat-based inventory of glaciers in western Canada, 1985-2005. Remote Sens. Environ., 114(1), 127-137 (doi: 10.1016/j.rse.2009.08.015)
Bulygina ON, Razuvaev VN and Korshunova NN (2009) Changes in snow cover over Northern Eurasia in the last few decades. Environ. Res. Lett., 4(4), 045026 (doi: 10.1088/1748-9326/4/4/ 045026)

Cogley JG (2009) Geodetic and direct mass-balance measurements: comparison and joint analysis. Ann. Glaciol., 50(50), 96-100 (doi: 10.3189/172756409787769744)

Cox LH and March RS (2004) Comparison of geodetic and glaciological mass-balance techniques, Gulkana Glacier, Alaska, U.S.A. J. Glaciol., 50(170), 363-370 (doi: 10.3189/ 172756504781829855)

DeBeer CM and Sharp MJ (2009) Topographic influences on recent changes of very small glaciers in the Monashee Mountains, British Columbia, Canada. J. Glaciol., 55(192), 691-700 (doi: 10.3189/002214309789470851)

Dolgushin LD (1961) Main features of the modern glaciation of the Urals. IASH Publ. 54 (General Assembly of Helsinki 1960 Snow and Ice), 335-347

Dyurgerov MB and Meier MF (2000) Twentieth century climate change: evidence from small glaciers. Proc. Natl. Acad. Sci. USA (PNAS), 97(4), 1406-1411

Evans IS (2011) Glacier distribution and direction in Svalbard, Axel Heiberg Island and throughout the Arctic: general northward tendencies. Pol. Polar Res., 32(3), 199-238

Fischer A (2011) Comparison of direct and geodetic mass balances on a multi-annual time scale. Cryosphere, 5(1), 107-124 (doi: 10.5194/tc-5-107-2011)

Glazovskiy AF, Nosenko GA and Tsvetkov DG (2005) Ledniki Urala: Sovremennoe sostoyanie i perspektivy evolyutsii [Glaciers of the Urals: current state and future]. Mater. Glyatsiol. Issled. 98, 207-213

Granshaw FD and Fountain AG (2006) Glacier change (19581998) in the North Cascades National Park Complex, Washington, USA. J. Glaciol., 52(177), 251-256 (doi: 10.3189/ 172756506781828782)

Groisman PYa and Rankova EYa (2001) Precipitation trends over the Russian permafrost-free zone: removing the artifacts of pre-processing. Int. J. Climatol., 21(6), 657-678 (doi: 10.1002/ joc.627)

Hoffman MJ, Fountain AG and Achuff JM (2007) 20thcentury variations in area of cirque glaciers and glacierets, Rocky Mountain National Park, Rocky Mountains, Colorado, USA. Ann. Glaciol., 46, 349-354 (doi: 10.3189/172756407782871233)

Kalnay E and 21 others (1996) The NCEP/NCAR 40-year reanalysis project. Bull. Am. Meteorol. Soc., 77(3), 437-471

Kaser G, Cogley JG, Dyurgerov MB, Meier MF and Ohmura A (2006) Mass balance of glaciers and ice caps: consensus estimates for 1961-2004. Geophys. Res. Lett., 33(19), L19501 (doi: 10.1029/2006GL027511)

Khodakov VG (1966) Oledenenie Urala: processy Idoobrazovaniya i stroenie lednikov [Glaciation of the Urals: processes of ice formation and structure of glaciers]. Glyaciologiya [Glaciology], 16, 221-256

Khodakov VG (1978) Vodno-ledovyy balans raionov sovremennogo i drevnego oledeneniya SSSR [Water and ice balance of regions of today and ancient glaciation of USSR]. Nauka, Moscow

Koblet T and 6 others (2010) Reanalysis of multi-temporal aerial images of Storglaciären, Sweden (1959-99) - Part 1: Determination of length, area, and volume changes. Cryosphere, 4(3), 333-343 (doi: 10.5194/tc-4-333-2010)

Kononov YuM and Ananicheva MD (2010) Otsenka izmenenii lednikov gor Byrranga po kosmicheskim snimkam i Katalogu Lednikov [Assessment of changes in glaciers of the Byrranga Mountains using satellite imagery and the Catalogue of Glaciers]. Led i Sneg, 3(111), 19-26

Kuhn M, Markl G, Kaser G, Nickus U, Obleitner F and Schneider H (1985) Fluctuations of climate and mass balance: different responses of two adjacent glaciers. Z. Gletscherkd. Glazialgeol., 21(1-2), 409-416 
Lang HR and Welch R (1999) ATBD-AST-08 algorithm theoretical basis document for ASTER digital elevation models (standard product AST14), Version 3.0. http://eospso.gsfc.nasa.gov/ eos_homepage/for_scientists/atbd/docs/ASTER/atbd-ast-14.pdf (accessed 13 April 2012)

Macheret YuYa and Zhuravlev AB (1981) Detal'naya radiolokatsionnaya s'yemka tolshchiny l'da podlednogo rel'yefa gornykh lednikov [Detailed radio-sounding survey of ice thickness and underlying topography of mountain glaciers]. Mater. Glyatsiol. Issled. 41, 115-133

Mangerud J, Gosse J, Matiouchkov A and Dolvik T (2008) Glaciers in the Polar Urals, Russia, were not much larger during the Last Global Glacial Maximum than today. Quat. Sci. Rev., 27(9-10), 1047-1057 (doi: 10.1016/j.quascirev.2008.01.015)

Oerlemans J and 10 others (1998) Modelling the response of glaciers to climate warming. Climate Dyn., 14(4), 267-274

Paul F and Andreassen LM (2009) A new glacier inventory for the Svartisen region, Norway, from Landsat ETM+ data: challenges and change assessment. J. Glaciol., 55(192), 607-618 (doi: 10.3189/002214309789471003)

Paul F, Kääb A, Maisch M, Kellenberger T and Haeberli W (2004) Rapid disintegration of Alpine glaciers observed with satellite data. Geophys. Res. Lett., 31(21), L21402 (doi: 10.1029/ 2004GL020816)

Paul F, Kääb A and Haeberli W (2007) Recent glacier changes in the Alps observed from satellite: consequences for future monitoring strategies. Global Planet. Change, 56(1-2), 111-122

Raup B, Racoviteanu A, Khalsa SJS, Helm C, Armstrong R and Arnaud Y (2007) The GLIMS geospatial glacier database: a new tool for studying glacier change. Global Planet. Change, 56(1-2), 101-110 (doi: 10.1016/j.gloplacha.2006.07.018)

Sapiano JJ, Harrison WD and Echelmeyer KA (1998) Elevation, volume and terminus changes of nine glaciers in North America. J. Glaciol., 44(146), 119-135

Shahgedanova M, Nosenko G, Khromova T and Muraveyev A (2010) Glacier shrinkage and climatic change in the Russian Altai from the mid-20th century: an assessment using remote sensing and PRECIS regional climate model. J. Geophys. Res., 115(D16), D16107 (doi: 10.1029/2009JD012976)

Shahgedanova M, Popovnin VV, Aleynikov A and Stokes CR (2011) Geodetic mass balance of Azarova glacier, Kodar mountains, eastern Siberia, and its links to observed and projected climatic change. Ann. Glaciol., 52(58), 129-137 (doi: 10.3189/ 172756411797252275)
Solomina O, Ivanov M and Bradwell T (2010) Lichenometric studies on moraines in the Polar Urals. Geogr. Ann., Ser. A, 92(1), 81-99 (doi: 10.1111/j.1468-0459.2010.00379.x)

Solomon S and 7 others eds (2007) Climate change 2007: the physical science basis. Contribution of Working Group I to the Fourth Assessment Report of the Intergovernmental Panel on Climate Change. Cambridge University Press, Cambridge

Takahashi S and 6 others (2011) Response of glaciers in the SuntarKhayata range, eastern Siberia, to climate change. Ann. Glaciol., 52(58), 185-192 (doi: 10.3189/172756411797252086)

Thibert E, Blanc R, Vincent C and Eckert N (2008) Glaciological and volumetric mass-balance measurements: error analysis over 51 years for Glacier de Sarennes, French Alps. J. Glaciol., 54(186), 522-532 (doi: 10.3189/002214308785837093)

Troitskiy LS and Kemmerikh AO (1966) Katalog lednikov SSSR Ural [Glacier Inventory of the USSR - Urals] Vol. 3, Part 3. Gidrometeoizdat, Leningrad

Troitskiy LS and 6 others. (1966) Oledenenie Urala [Glaciation of the Urals]. Nauka, Moscow

Tsvetkov DG (1969) Opredelenie izmeneniya ob'emov gornyh lednikov po materialam stereofotorgammetricheskih s'emok [Calculating changes in volumes of mountain glaciers using terrestrial photogrammetry]. Mater. Glyatsiol. Issled. 15, 182-191

Tsvetkov DG (2006) Fotogeodezicheskii monitoring lednikov Polyarnogo Urala [Monitoring of the Polar Urals glaciers using geodetic and aerial photography surveys]. In Kotlyakov VM ed. Oledenenie Severnoj i Central'noj Evrazii v Sovremennuju epochu [Glaciation in north and central Eurasia at present time]. Nauka, Moscow

Tsvetkov DG and Tyuflin AS (1981) Katastroficheskaya degradatsiya lednika MGU na Polyarnom Urale [Catastrophic degradation of the MGU glacier in the Polar Urals]. Mater. Glyatsiol. Issled. 41, 162-172

Uppala SM and 45 others (2005) The ERA-40 re-analysis. Q. J. R. Meteorol. Soc., 131(612), 2961-3212 (doi: 10.1256/ qj.04.176)

Voloshina AP (1988) Some results of glacier mass balance research on the glaciers of the polar Urals. Polar Geogr. Geol., 12(3), 200-211

Zemp M and 6 others (2010) Reanalysis of multi-temporal aerial images of Storglaciären, Sweden (1959-99). Part 2: Comparison of glaciological and volumetric mass balances. Cryosphere, 4(3), 345-357 (doi: 10.5194/tc-4-345-2010)

MS received 14 November 2011 and accepted in revised form 11 April 2012 